\title{
THE ENGLISH-LANGUAGE PROFICIENCY OF RECENT IMMIGRANTS IN THE U.S. DURING THE EARLY 1900s
}

\author{
Anthony P. Mora \\ Texas A\&M University \\ Marie T. Mora \\ University of Texas-Pan American \\ and \\ Alberto Dávila \\ University of Texas-Pan American
}

\section{INTRODUCTION}

One seeming implication of the rising visibility of immigrants in the United States in recent years is the surge in xenophobia and intolerance to linguistic pluralism. Sweeping immigration reform has followed, along with unsuccessful attempts to declare English as this country's official language. These types of policy reactions are not novel, at least not in the U.S. At the turn of the twentieth century, when the foreign-born comprised a higher share of the American population than today, ${ }^{1}$ similar threads of xenophobia existed.

Indeed, during the early 1900s, the rise in Slavic and Mediterranean immigration spawned a dramatic period of anti-immigrant fervor. Many native business leaders and editorials expressed racist presumptions of Anglo-Saxon, Aryan, and Teutonic superiority over "new" immigrants, often regarded as "inassimilable" [e.g., King, 2000; Nugent, 1992; Curran, 1975]. While American histories from Oscar Handlin's The Uprooted to John Bodnar's The Transplanted: A History of Immigrants in Urban America (and beyond) have debated the plight of these turn-of-the-century immigrants, few have sought to study the English-language fluency of immigrants at that time.

We utilize U.S. decennial census data from 1900, 1910, and 1920 in the Integrated Public Use Microdata Series (IPUMS) provided by Ruggles and Sobek [1997] to empirically analyze changes in the English-language fluency of immigrants who arrived

Marie T. Mora: Department of Economics and Finance, College of Business Administration, University of Texas-Pan Amerian, Edinburg, TX 78541. E-mail: mtmora@utpa.edu.

Eastern Economic Journal, Vol. 33, No. 1, Winter 2007 
to the U.S. within three years of each census. According to the extant literature of more recent time periods [e.g., Dávila and Mora, 2000a; 2000b], rising xenophobia and increasing returns to English-language proficiency induced limited-English proficient (LEP) populations to invest in English skills. Our primary findings for the early 1900s parallel these predictions: immigrants in 1920 (particularly those from Southern and Eastern Europe) were more likely to speak English within three years of migrating to the U.S. than their counterparts had been in either 1900 or 1910 . These results suggest that immigrants reacted to the changing socioeconomic and political conditions during the early 1900s by investing in English-language skills and/or by selectively migrating on the basis of English-language fluency.

\section{BACKGROUND AND CONCEPTUAL ISSUES}

Conventional wisdom suggests that the acquisition of English-language fluency costs time, effort, and financial resources. According to human capital theory, however, English proficiency enhances labor market and social opportunities in employment possibilities, earnings, and trade. ${ }^{2}$ We hypothesize that changes in socioeconomic and political conditions in the early 1900s impacted both the benefits and the costs of English-language acquisition, especially for those recent arrivals to the U.S. This section discusses three related phenomena supporting this hypothesis: (1) rising xenophobia and subsequent immigration restrictions on non-English-speaking populations, (2) changing labor market conditions that seemed to favor the English-fluent, and (3) selective immigration and emigration.

\section{Xenophobia and Immigration Policies in the U.S.}

Since the colonial period, immigration policy has been a topic of much debate. Starting in the mid-1800s, massive immigration from Germany, Ireland, and China spurred widespread nativist sentiments, ${ }^{3}$ as evidenced by the formation of the Native American party of the 1830s, the American Republican party of the 1840s, and the Know-Nothings of the 1850s [Cohn, 2000; King, 2000; Curran, 1975]. Moreover, while the U.S. Congress encouraged immigration to ease labor shortages after the Civil War [Wittke, 1949; Roberts, (1912) 1914], by the late 19th Century many non-Hispanic whites, driven by xenophobic ideals, lobbied for legal restrictions on immigration and citizenship. Belief in "white superiority" (defined in terms of Anglo-Saxon, Teutonic, or Aryan ancestry), as well as the demands by organized labor, led Congress to pass some of the first immigration legislation at the national level. ${ }^{4}$

These anti-immigrant sentiments were accentuated (and occasionally led to violence) as large waves of "new" immigrants-those from Southern and Eastern Europe-entered the U.S. during the late 1800s and early 1900s. ${ }^{5}$ Popular discourse began to deem language as a specific marker that differentiated between "Americans" and "foreigners." Many established Americans viewed the foreign-born who did not speak English as "un-American" and unwilling to assimilate [e.g., Higham, 1988]. Organizations including the American Protective Association (formed in 1887) and the Immigration Restriction League (formed in 1894) became increasingly active in advocating selective immigration legislation at that time [Curran, 1975; Archdeacon, 1983; King, 2000]. 
Political reactions to these sentiments are reflected in the Naturalization Act of 1906, which standardized the naturalization process and included English fluency as a key requirement for citizenship. Soon after, the Immigration Act of 1907 created a Joint Commission on Immigration whose 42-volume report, released in 1911, served as a cornerstone for the controversial Immigration Act of $1917 .{ }^{7}$ The controversy revolved around this act's literacy requirement which mandated that immigrant men above the age of 15 would need to prove literacy in at least one language (though not necessarily in English). ${ }^{8}$ Proponents of this measure predicted it would vastly reduce the immigration flow from Southern and Eastern Europe [e.g., King, 2000; Higham, 1988; Curran, 1975]. Economist John Commons, a member of the Immigration Restriction League, stated that this literacy test “...would exclude only one in 200 of the Scandinavians, one in 100 of the English, Scotch, and Finns, two or three in 100 of the Germans, Irish, Welch, and French; but it would exclude one-half of the South Italians, one-seventh of the North Italians, one-third to two-fifths of the several Slav races, one-seventh of the Russian Jews, altogether one-fifth or one-fourth of the total immigration" [(1907) 1911, 234-35].

The years around World War I further kindled such movements as "One Hundred Percent Americanism" and "Americanization" campaigns that promoted efforts to encourage immigrants to learn English as rapidly as possible. ${ }^{9}$ Workers at over 800 industrial plants had access to some type of Americanization program by 1919, most of which were developed in the mid- to late 1910s [King, 2000]. Henry Ford actively followed this campaign in 1915 by requiring his foreign employees to attend his recently created Ford English School two days a week [Higham, 1988]. ${ }^{10}$

\section{English Fluency and Labor Market Opportunities.}

Arguably, the social and political benefits of English-language fluency increased around the turn of the last century and strengthened in the years surrounding World War I. Structural changes in the U.S. labor market during the early 1900s reinforced the growing socioeconomic importance of the language. By then, learning English presumably would have expanded inter-ethnic communication between workers from diverse language backgrounds through a common language. ${ }^{11}$ Evidence based on earnings data in the Immigration Commission's 1911 report indeed suggests that English fluency increased the average earnings of immigrant men at that time [Blau, 1980; McGouldrick and Tannen, 1977; Higgs, 1971].

The appendix discusses changes in the occupational distributions of recently-arrived immigrants along the lines of English-language fluency. These distributions indicate that the inverse relationship between the inability to speak English and working in professional, managerial, and technical vocations significantly intensified between 1900 and 1920, even when controlling for other observable characteristics. The shift away from higher-status into lower-status jobs among the LEP in particular signals a tightening of labor market conditions experienced by incoming immigrants unable (or unwilling) to learn the English language after 1900.

These findings are consistent with the rising industrialization of America during that time. Hourwich [(1912) 1971, 289], for example, noted that "the rapid pace of industrial expansion has increased the number of skilled and supervisory positions so fast that practically all of the English-speaking employees have had the opportunity 
to rise on the scale of occupations."12 Another explanation of the tighter labor market conditions for LEP immigrants is that many businesses which provided Americanization programs around World War I could have limited their hiring of English-deficient employees or passed along some of the program costs via lower earnings. A third possibility involves an increase in xenophobic employers' "psychic costs" of hiring LEP workers and rising consumer discrimination against the LEP during this period, reducing the employment opportunities of the LEP [e.g., Becker, 1971]. Overall, this discussion suggests that immigrants who spoke English poorly were at an increased labor market disadvantage by 1920. As noted by Viscusi [1980], fewer employment opportunities for a group worsen their overall labor market outcomes.

\section{Selective Immigration and Emigration.}

The changing labor market conditions in the early 1900s might have also affected the selective migration patterns of the foreign-born. This possibility is consistent with Roy [1951], who discussed how selective movements occur with respect to the relative spread of income distributions. The labor market shift that seemed to favor English-proficient workers after 1900 could have skewed the net immigration flow toward the foreign-born with greater propensities for English procurement or with stronger English-language skills.

World War I further transformed immigration (and remigration) possibilities and potentially the English-proficiency rates of the foreign-born in the U.S. Historical statistics provided by the U.S. Bureau of Citizenship and Immigration Services [2002] displayed in Figure 1 show a dramatic increase in the number of immigrants arriving to the U.S. just before 1900. Immigration sharply declined after 1914 and reached a trough in 1918 when the number of immigrants admitted into the U.S. fell below the level admitted twenty years earlier. Consequently, in the years around the War, the foreign-born might have found that learning English represented a means to facilitate entry into the U.S. and to assimilate into the mainstream American culture, especially with the greater opportunities to do so during the Americanization movements that flourished during the War.

\section{Discussion.}

The sum of these events implies that the socioeconomic and political benefits of English-language fluency increased after 1900, particularly around World War I. Owing to differences in socioeconomic and demographic characteristics, however, the English-proficiency investments were most likely disproportional across immigrants. While the benefits associated with understanding the English language rose in the early 1900s, the marginal benefits of acquiring this skill were likely greater for immigrants actively engaged in and committed to mainstream American society, such as men who had higher labor force participation rates than women. ${ }^{13}$ Populations experiencing the strongest degrees of xenophobia at that time, including those from Southern and Eastern Europe, may have also perceived a relatively large marginal benefit from learning English. Moreover, while language investments negatively relate to cost, the marginal cost of acquiring additional English skills may have been relatively small for those with the lowest initial English fluency, such as immigrants just 
arriving to the U.S., because English-acquisition costs presumably exhibit convexity properties [Dávila and Mora, 2000a].

FIGURE 1

Immigrant Aliens Admitted to the U.S.: 1890 - 1930

Source: U.S. Bureau of Citizenship and Immigration Services [2003]

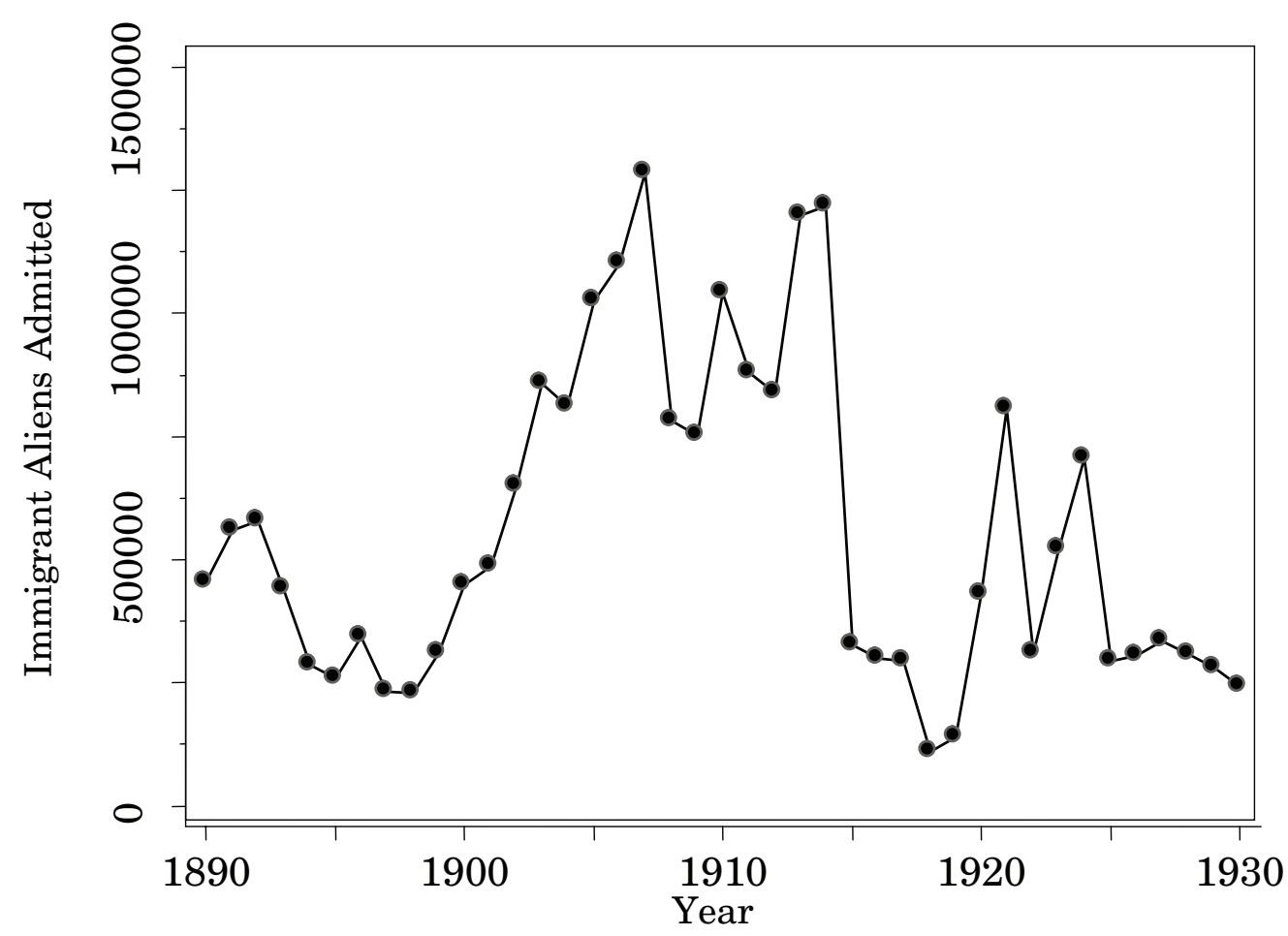

Emerging from this discussion is the hypothesis that foreign-born residents in the U.S. responded to the socioeconomic and political changes after 1900 (especially after World War I) by investing in English-language skills and/or selectively migrating on the basis of linguistic capabilities. These investments, however, probably varied with respect to immigrants' demographic and socioeconomic characteristics.

\section{DATA AND EMPIRICAL ANALYSIS}

To investigate whether the English-language proficiency of recent immigrants in the U.S. changed during the early 1900 s, we utilize decennial census data from 1900 , 1910 and 1920 available in the Integrated Public Use Microdata Series (IPUMS) provided by Ruggles and Sobek [1997]. In all analyses below, we employ the IPUMSprovided statistical weights to maintain the national representation of the sample. In addition to standard information such as gender and birthplace, these early censuses 
include data on whether immigrants spoke English. ${ }^{14}$ The 1910 and 1920 censuses also contain information on individuals' mother-tongues; we construct a proxy measure for the mother-tongue in the 1900 survey based on the most commonly reported mother-tongue in 1910 among individuals with the same birthplace. Information on the native language allows for the identification of English-speakers among those who were not native-English speakers.

Our sample of interest contains immigrants aged 16 and older who had migrated to the U.S. within three years of each census. That is, the sample analyzed here consists of individuals who arrived to the U.S. between 1897-1900 in the 1900 IPUMS, 1907-1910 in the 1910 IPUMS, and 1917-1920 in the 1920 IPUMS. This three-year restriction reduces the likelihood that the sample has been biased by the relatively high remigration patterns of the Southern and Eastern Europeans [e.g., see Archdeacon, 1983, particularly Table V-4]. While individuals migrating between 1917-20 may be considered atypical in terms of immigrant arrivals in that era given their drastically reduced numbers compared to earlier years (as observed in Figure 1 above), this population is important to analyze because it would have been directly affected by the Immigration Act of 1917. Recall that this act imposed a literacy requirement under the assumption that it would shift the immigration flow toward relatively skilled (and probably, English-fluent) immigrants.

Table 1 shows the proportion of the English-fluent, as well as those with an English mother-tongue, out of the entire recent immigrant sample in each census year. In 1900, nearly 30 percent of all recent immigrants had an English-mother-tongue, and over half spoke English. These numbers fell sharply by 1910: native English-speakers represented less than 12 percent of all recent immigrants, and only slightly more than a third spoke English. By 1920, however, native-English speakers represented about 24 percent of all recent immigrants; while this figure is slightly below the 1900 level, the total share of English speakers in 1920 increased above the 1900 level, to 63 percent. These changes are consistent with the expectations that events such as the 1917 Immigration Act, rising xenophobia during World War I, tightening labor market conditions for the LEP, and the growing presence of Americanization programs spurred many immigrants to learn English shortly after migration or to selectively migrate on the basis of this skill.

The English-proficiency rates of recent immigrants who were not native-English speakers reveal additional interesting patterns. Less than 40 percent of this group spoke English within three years of migrating to the U.S. in 1900, compared to over 50 percent in 1920 . The odds ratios reported in Table 1 emphasize these patterns. ${ }^{15}$ Recently-arrived immigrants with non-English mother-tongues in 1920 were nearly 1.7 times more likely to be English-fluent instead of LEP compared to those in 1900 . Moreover, recent immigrants from Southern and Eastern Europe displayed a stronger shift towards English proficiency, as the share of English speakers from these countries doubled between 1900 and 1920 .

We suspect these findings reflect socioeconomic and political events, including immigration policy, changing labor market conditions, rising industrialization, and the Americanization programs, that most likely worked in tandem to stimulate English acquisition among recent immigrants. The remainder of our analyses explores this conjecture by specifically focusing on immigrants with non-English mother-tongues. 
TABLE 1

Percentages of Recent Immigrants Who Were Fluent in the English Language

\begin{tabular}{|c|c|c|c|c|c|}
\hline \multirow[b]{2}{*}{ Category } & \multirow[b]{2}{*}{1900} & \multirow[b]{2}{*}{1910} & \multirow[b]{2}{*}{1920} & \multicolumn{2}{|c|}{$\begin{array}{l}\text { Odds Ratio of Speaking } \\
\text { English to Being LEP: }\end{array}$} \\
\hline & & & & $1920 / 1900$ & $1920 / 1910$ \\
\hline \multicolumn{6}{|l|}{ All recent immigrants } \\
\hline English mother-tongue & $29.3 \%$ & $11.7 \%$ & $23.9 \%$ & ----- & ----- \\
\hline Speaks English & $53.6 \%$ & $36.7 \%$ & $62.8 \%$ & 1.46 & 2.91 \\
\hline \multicolumn{6}{|c|}{ Recent immigrants with non-English mother tongues } \\
\hline Speaks English & $38.3 \%$ & $28.3 \%$ & $50.6 \%$ & 1.65 & 2.59 \\
\hline \multicolumn{6}{|c|}{ Southern and Eastern Europeans } \\
\hline Speaks English & $27.7 \%$ & $20.9 \%$ & $57.9 \%$ & 3.59 & 5.21 \\
\hline
\end{tabular}

Notes: These distributions contain immigrants aged 16 and above who had migrated to the U.S. within three years of each census in the IPUMS. Pearson $\chi^{2}$ tests were used to determine if the distributions statistically differed between 1900 and 1920, and between 1910 and 1920. All were statistically different at the one percent level.

Table 2 provides mean characteristics of the recent immigrant samples in each census year. According to this table, those who spoke English tended to reside in areas with lower language minority concentrations on average and had higher literacy rates (the ability to read and write) than the LEP. The language concentration measure was constructed by dividing the number of immigrants with the same mother-tongue by the population of the county in each census year. For example, for an Italian immigrant residing in County $\mathrm{X}$, the variable measures the population share of native-Italian speakers in X. Immigrants in the same county do not have the same language concentration value if they have different mother-tongues. Individuals with mother-tongues spoken by less than one percent of immigrants in all of the censuses were assigned a "zero" to this measure because such small language groups (in some cases, only one or two speakers in the IPUMS) are not, by default, linguistically concentrated.

\section{TABLE 2}

Mean Characteristics of Recent Immigrants with Non-English Mother-Tongues

\begin{tabular}{lcccccc}
\hline \multirow{2}{*}{ Characteristic } & \multicolumn{3}{c}{ Speaks English } & \multicolumn{3}{c}{ Does Not Speak English } \\
Language concentration & $\mathbf{1 9 0 0}$ & $\mathbf{1 9 1 0}$ & $\mathbf{1 9 2 0}$ & $\mathbf{1 9 0 0}$ & $\mathbf{1 9 1 0}$ & $\mathbf{1 9 2 0}$ \\
\hline & 0.193 & 0.187 & 0.166 & 0.210 & 0.236 & 0.410 \\
Years in U.S. & $(0.186)$ & $(0.189)$ & $(0.204)$ & $(0.202)$ & $(0.236)$ & $(0.327)$ \\
& 1.822 & 2.179 & 1.886 & 1.342 & 1.679 & 1.768 \\
Age & $(1.009)$ & $(0.927)$ & $(0.923)$ & $(1.014)$ & $(1.075)$ & $(0.887)$ \\
& 27.003 & 26.675 & 30.969 & 29.152 & 29.089 & 31.235 \\
Southern or Eastern European & $(9.836)$ & $(9.538)$ & $(12.408)$ & $(10.481)$ & $(10.325)$ & $(12.177)$ \\
Asian & 0.384 & 0.414 & 0.361 & 0.623 & 0.620 & 0.270 \\
Female & 0.024 & 0.041 & 0.100 & 0.036 & 0.044 & 0.089 \\
Literate & 0.383 & 0.364 & 0.384 & 0.347 & 0.310 & 0.466 \\
Single & 0.880 & 0.873 & 0.885 & 0.499 & 0.634 & 0.552 \\
N (unweighted) & 0.624 & 0.646 & 0.491 & 0.483 & 0.472 & 0.372 \\
N(weighted) & 880 & 1,801 & 1,486 & 1,417 & 4,561 & 1,452 \\
Notes: The part & 176,000 & 453,666 & 149,955 & 283,400 & $1,148,877$ & 146,537 \\
\hline
\end{tabular}

Notes: The parentheses contain standard deviations for the continuous variables. The samples include immigrants aged 16 and above who arrived within three years of each census date in the IPUMS, and who did not have an English mother-tongue. 
Note that the average language concentration in the communities in which the LEP resided increased between 1900 and 1920, but it fell for those who spoke English. This rising clustering-propensity of incoming LEP immigrants in particular might reflect deteriorating labor market conditions for those with poor English-language skills, particularly those facing a large expense in acquiring these skills [e.g., Lazear 1999]. Alternatively, the larger concentration of LEP immigrants could itself have contributed to xenophobia, given that the concentration and visibility of minority groups have been linked to taste-based discrimination [Becker, 1971].

Other observations in Table 2 indicate underlying demographic changes in the recent immigrant populations during the early 1900s. For example, in 1900 and 1910, those who spoke English had resided in the U.S. about half a year longer than their LEP counterparts. By 1920, the difference in U.S.-tenure between the English-fluent and English-deficient was less than 1/12 of a year. Changes in the age distributions also occurred over the two decades: in 1900, recent immigrants who spoke English were younger on average than those who did not, but this pattern reversed by 1920 .

\section{Multivariate Analysis.}

To empirically test whether the increases in English-language fluency observed in Table 1 hold net of changes in the demographic factors displayed in Table 2, we estimate a logit regression with English-language fluency as the dependent variable:

(1) English Fluent $*=V \beta_{0}+(V x 1910$ IPUMS $) \beta_{1}+(V x 1920$ IPUMS $) \beta_{2}+e$.

English Fluent* represents an unobserved latent variable for English-language proficiency; we observe fluency equal to 1 if English Fluent* ${ }^{*}>0$, and it equals 0 otherwise. $V$ denotes a vector of observed socioeconomic and demographic characteristics often found related to English fluency in the literature, ${ }^{16}$ including birthplace, gender, years in the U.S. (ranging from 0 to 3), language concentration, age, literacy, marital status, and residence in a rural area. Vx 1910 IPUMS and Vx 1920 IPUMS represent vectors of the interactions between all variables in $V$ and binary variables indicating if the individual is in the 1910 or 1920 IPUMS. These interactions account for changes in the model's structure related to the English-fluency of recent immigrants between 1900 and 1920. The $\beta_{i}$ 's depict vectors of coefficients to be estimated, and finally $e$ represents the error term where $E(e)=0$ and $\operatorname{Var}(e)=1$.

Table 3 provides the empirical results from estimating Equation (1) for the entire sample as well as a sample comprised of recent immigrants from Southern and Eastern Europe. The coefficient on 1910 IPUMS indicates that when controlling for observable characteristics, recent immigrants arriving to the U.S. from 1907 to 1910 were less likely to speak English than their counterparts who migrated between 1897 and 1900 had been in 1900. Nevertheless, the statistically significant (at the one-percent level) coefficients on the 1920 IPUMS variable for both samples show that in 1920 , recent immigrants had been more likely to speak English than their earlier counterparts had been within three years of migrating, ceteris paribus. That is, immigrants appear to have responded to the socioeconomic and political events occurring in the 1910s by learning English relatively rapidly after migrating to the U.S. The events during that decade may have also shifted the immigration flow in favor of those with a greater capacity (or willingness) to learn the language. 
TABLE 3

Logit Regression Results for the English-Language Fluency of Recent Immigrants with Non-English Mother-Tongues (Dependent Variable = 1 if the Individual Speaks English; = 0 Otherwise) Entire Sample

Southern \&

Eastern European

\begin{tabular}{|c|c|c|c|c|}
\hline$\overline{\text { Variable }}$ & Coefficient & $\begin{array}{c}\text { Standard } \\
\text { Error }\end{array}$ & Coefficient & $\begin{array}{c}\text { Standard } \\
\text { Error } \\
\end{array}$ \\
\hline 1910 IPUMS & $-0.625^{*}$ & 0.331 & -0.330 & 0.468 \\
\hline 1920 IPUMS & $1.019 * * *$ & 0.360 & $1.558 * * *$ & 0.540 \\
\hline Southern or Eastern European & $-0.872^{* * *}$ & 0.107 & ---- & ---- \\
\hline Southern or Eastern European x 1910 IPUMS & -0.070 & 0.125 & ----- & ----- \\
\hline Southern or Eastern European x 1920 IPUMS & $0.674 * * *$ & 0.148 & ----- & ----- \\
\hline Asian & $-1.072^{* *}$ & 0.306 & ----- & ----- \\
\hline Asian x 1910 IPUMS & 0.372 & 0.343 & ----- & ----- \\
\hline Asian x 1920 IPUMS & $0.801 * *$ & 0.340 & ---- & ---- \\
\hline Years in U.S. & $0.507 * * *$ & 0.050 & $0.486^{* * *}$ & 0.074 \\
\hline Years in U.S. x 1910 IPUMS & 0.038 & 0.059 & 0.116 & 0.087 \\
\hline Years in U.S. x 1920 IPUMS & $-0.336 * * *$ & 0.069 & $-0.202^{*}$ & 0.108 \\
\hline Female & 0.123 & 0.110 & -0.018 & 0.163 \\
\hline Female x 1910 IPUMS & 0.145 & 0.129 & 0.019 & 0.191 \\
\hline Female x 1920 IPUMS & $-0.442^{* * *}$ & 0.143 & $-0.367^{*}$ & 0.221 \\
\hline Language concentration & $-1.300 * * *$ & 0.298 & $-1.955^{* * *}$ & 0.681 \\
\hline Language con. x 1910 IPUMS & 0.253 & 0.339 & 1.201 & 0.754 \\
\hline Language con. x 1920 IPUMS & $-1.859 * * *$ & 0.354 & 0.659 & 0.884 \\
\hline Age & -0.009 & 0.006 & $-0.018^{* *}$ & 0.009 \\
\hline Age x 1910 IPUMS & 0.003 & 0.007 & -0.010 & 0.011 \\
\hline Age x 1920 IPUMS & $0.016 * *$ & 0.007 & 0.010 & 0.011 \\
\hline Literate & $1.865^{* * * *}$ & 0.124 & $1.771^{* * * *}$ & 0.164 \\
\hline Literate x 1910 IPUMS & $-0.671^{* * *}$ & 0.148 & $-0.833^{* * *}$ & 0.191 \\
\hline Literate x 1920 IPUMS & -0.196 & 0.163 & -0.520 & 0.228 \\
\hline Single & $0.261^{* *}$ & 0.120 & -0.005 & 0.171 \\
\hline Single x 1910 IPUMS & $0.451^{* * * *}$ & 0.141 & $0.355^{*}$ & 0.204 \\
\hline Single x 1920 IPUMS & 0.056 & 0.155 & -0.055 & 0.236 \\
\hline Rural area & -0.059 & 0.113 & 0.167 & 0.168 \\
\hline Rural x 1910 IPUMS & -0.195 & 0.138 & $-0.590 * * *$ & 0.214 \\
\hline Rural x 1920 IPUMS & -0.071 & 0.151 & 0.145 & 0.275 \\
\hline Constant & $-1.806^{* * *}$ & 0.282 & $-2.101^{* * *}$ & 0.397 \\
\hline $\begin{array}{l}\chi^{2} \text { test for } 1910 \text { IPUMS } \\
\text { coefficient }=1920 \text { IPUMS }\end{array}$ & $33.74^{* * *}$ & & $18.14^{* * *}$ & \\
\hline Pseudo $\mathrm{R}^{2}$ & .186 & & .151 & \\
\hline $\mathrm{N}$ (unweighted) & 11,597 & & 5,722 & \\
\hline
\end{tabular}

***, **, * Statistically significant at the one, five, and ten percent levels.

Notes: The reported standard errors are robust. Other binary variables in the analysis (not shown to conserve space, but available from the authors) include geographic region [West, Midwest, South, and Northeast (base)] and an indicator for missing information on English fluency. The sample includes recent immigrants ages 16 and above in the IPUMS who did not have an English mother-tongue.

The positive and significant coefficients on Southern \& Eastern European x 1920 IPUMS and Asian x 1920 IPUMS suggest that 1917-1920 entrants from these countries had an even greater likelihood of being fluent in English within three years of migrating compared to other recent immigrants when controlling for other characteristics. Given that the xenophobic elements (and the 1917 Immigration Act itself) often targeted Mediterranean, Slavic, and Asian immigrants, these results imply that they reacted by learning English more quickly than their previous counterparts. Re- 
inforcing these findings is the negative and statistically significant coefficient on the interaction between U.S.-tenure and 1920 IPUMS. Despite only spanning a three-year period, U.S.-tenure played a weaker role on the propensity to speak English among recent immigrants in 1920 compared to 1900 and 1910.

Table 3 further shows that while recently-arrived immigrant women in 1900 and 1910 had been as likely to speak English as their male counterparts, foreign-born women had significantly lower propensities to speak English in 1920. This change may have been in response to the growing importance of English proficiency with respect to labor market outcomes, given the relatively high labor force participation of foreignborn men. Another explanation is that the literacy requirement in the Immigrant Act of 1917 pertained only to men, such that the shift in the immigration flow favoring greater English ability would have presumably been less pronounced for women.

Finally, similar to the mean characteristics observed in Table 2 above, residing in areas with high language concentrations related to low propensities to speak English, particularly in 1920. Of course, the inverse relationship between English fluency and language concentration is probably not causal because LEP individuals often sort into regions characterized by fellow-language speakers [e.g., Lazear, 1999; Jasso and Rosenzweig, 1989]. The negative and significant coefficient on the interaction between language concentration and the 1920 IPUMS variable reveals a stronger tendency for recent immigrants unable to speak the English language in 1920 to locate in areas with high language concentrations. This finding suggests that while larger shares of recent immigrants were acquiring English-language proficiency, those who did not (or could not) were finding it increasingly important to cluster with fellow immigrants, possibly to shield themselves from the rising xenophobia and deteriorating labor market conditions. As mentioned above, however, the growing geographic concentrations of the LEP could have been a contributing factor in creating xenophobia.

\section{CONCLUDING REMARKS}

Our findings using U.S. decennial census data suggest that many recently-arrived immigrants in the U.S. responded to socioeconomic and political events during the early 1900s by investing in English-language skills and/or by selectively migrating on the basis of linguistic capacities. Such events included rising xenophobia, changing labor market conditions, immigration restrictions, and the Americanization campaign and industrialization effects around World War I. By empirically tracing the changing rates of English fluency among recent immigrants over this period, this study provides historical insight into some pressures and decisions that foreign-born individuals seemingly faced to learn the English language in the early 1900s.

While we remain agnostic on which of the aforementioned events might have had the strongest impact, the issue of xenophobia deserves policy attention, particularly in light of some current sentiments observed in the U.S. following September 11, 2001. To what extent, for example, does xenophobia cluster those who speak English poorly into ethnic enclaves and reduce their labor market opportunities? Moreover, xenophobic movements and subsequent legislation have historically been linked to a host of atrocities and a loss of civil liberties. Those in the U.S. include the periodic 
violence against Italian immigrants at the turn of the twentieth century (see Note 5), the mass repatriation of Mexicans and Mexican Americans during the Depression, and the detention of Japanese Americans against their will during World War II. Such zealous ethnocentricism should dispel the view that the potential benefits associated with xenophobic pressures are justified and outweigh the costs.

It also remains unclear whether anti-immigrant sentiments enhance the overall skill profiles of individuals. If the foreign-born acquire and intergenerationally transfer English at the expense of discarding their native languages, then the productivity increases and gains from trade related to the English-language attainment might be overstated, particularly in modern times. Linguistic pluralism is clearly becoming an increasingly valuable asset as countries more actively engage in trade with linguistically-diverse economic regions such as the European Union. As such, it behooves policymakers to consider more "gentle" means to promote language investments. Of course, we cannot determine from our analysis how much of the changes in English fluency among recent immigrants in the U.S. during the early 1900s specifically stemmed from the sources mentioned above. Arguably, more work relating immigration policies to language portfolios warrants future investigation.

\section{APPENDIX \\ English-Language Fluency and Occupational Status in the Early 1900s}

Our analysis of the relationship between English proficiency and the occupational status of recently arrived immigrants in the early 1900s relies on 1900, 1910, and 1920 decennial census data available in the Integrated Public Use Microdata Series (IPUMS). The sample used in this appendix includes immigrant men who reported an occupation, were at least 16 years old, and had migrated within three years of each census. We exclude women from this analysis because of their drastically low representation in the labor force during that time; in these three census years, women accounted for only 15 percent of all recently-arrived foreign-born workers in the IPUMS.

Table A1 presents the occupational distributions of all recent immigrant men and Southern and Eastern European men in each year according to their ability to speak the English language. Three features should be highlighted. First, consistent with conventional wisdom, recent immigrants, including those from Southern and Eastern Europe, who did not speak English were less likely to have "white collar" occupations than those who spoke the language. Second, this LEP/English-fluent occupational gap widened between 1900 and 1920 because the share of immigrant men who spoke English in higher status jobs increased, while the representation of the LEP in such vocations declined. Third, the proportion of agricultural workers among all recent LEP immigrant men tripled (from 6.6 to 21.4 percent) between 1900 and 1920, but it fell by a third (from 13.9 to 9.4 percent) among those who spoke English. The rising share of agricultural workers also occurred among LEP immigrants from Southern and Eastern Europe, albeit at a less dramatic pace. On the surface, these distributions are consistent with the growing importance of English-language fluency with respect to labor market opportunities in the early 1900 s. 
TABLE A1

Occupational Distributions of Recent Immigrant Men by English-Language Fluency Status

\begin{tabular}{|c|c|c|c|}
\hline Occupation & 1900 & 1910 & 1920 \\
\hline \multicolumn{4}{|l|}{ Speaks English } \\
\hline Professional, technical, managerial & $6.7 \%$ & $6.8 \%$ & $10.6 \%$ \\
\hline Services, sales, clerical & 12.0 & 13.6 & 17.2 \\
\hline Non-farm laborer and other blue collar & 67.4 & 66.4 & 62.9 \\
\hline Agricultural & 13.9 & 13.2 & 9.4 \\
\hline \multicolumn{4}{|c|}{ Speaks English with non-English mother-tongue } \\
\hline Professional, technical, managerial & 6.0 & 7.1 & 9.7 \\
\hline Services, sales, clerical & 12.4 & 13.1 & 13.8 \\
\hline Non-farm laborer and other blue collar & 66.4 & 68.1 & 65.1 \\
\hline Agricultural & 15.2 & 11.8 & 11.4 \\
\hline \multicolumn{4}{|l|}{ Does not speak English } \\
\hline Professional, technical, managerial & 2.3 & 1.7 & 1.2 \\
\hline Services, sales, clerical & 5.7 & 3.3 & 3.6 \\
\hline Non-farm laborer and other blue collar & 85.4 & 86.7 & 73.8 \\
\hline Agricultural & 6.6 & 8.3 & 21.4 \\
\hline \multicolumn{4}{|c|}{ Southern \& Eastern European, Speaks English } \\
\hline Professional, technical, managerial & 6.5 & 7.7 & 9.7 \\
\hline Services, sales, clerical & 11.1 & 12.8 & 14.8 \\
\hline Non-farm laborer and other blue collar & 72.4 & 74.4 & 71.1 \\
\hline Agricultural & 10.1 & 5.1 & 4.4 \\
\hline \multicolumn{4}{|c|}{ Southern \& Eastern European, Does not speak English } \\
\hline Professional, technical, managerial & 1.8 & 1.8 & 1.2 \\
\hline Services, sales, clerical & 4.9 & 3.9 & 4.6 \\
\hline Non-farm laborer and other blue collar & 88.0 & 89.5 & 87.4 \\
\hline Agricultural & 5.3 & 4.8 & 6.9 \\
\hline
\end{tabular}

Note: Some of the distributions may not sum to 100 percent because of rounding.

Still, changes with respect to other underlying characteristics, such as literacy and age, in the net immigration flow could have driven these occupational shifts. As such, we conduct a more detailed analysis of how English fluency related to the vocational status of recent immigrant men by estimating an occupational multinomial logit (with the base group comprised of professional, managerial, and technical vocations) that controls for limited-English ability and other observable factors, including literacy (defined as the ability to read and write), age, years in the U.S., being from Southern and Eastern Europe or Asia, and the U.S. geographic region. These characteristics are also interacted with binary variables equal to one for individuals in the 1910 IPUMS and the 1920 IPUMS to determine whether their influence differently affected occupational distributions in the subsequent years compared to 1900.

To conserve space, Table A2 reports the regression results for the LEP and literacy variables for all recent immigrant men as well as for those with non-English mother-tongues; the remaining results can be obtained from the authors. Table A2 shows that, consistent with expectations, recently-arrived foreign-born men unable to speak the English language in 1900 were more likely to be non-farm laborers instead of professionals and managers than their otherwise similar peers. In that year, however, English proficiency was not significantly related to employment in service, sales, clerical, or agricultural positions vis-à-vis professional, managerial, and technical vocations, ceteris paribus. Nevertheless, by 1910, and even more so by 1920 , the relationship significantly strengthened between the inability to speak English and 
likelihood of working as farm and non-farm laborers and in other blue collar positions relative to white collar positions when controlling for other characteristics.

\section{TABLE A2}

\section{Selected Multinomial Logit Results for the} Occupational Sorting of Recent Immigrant Men

(Base Occupational Category: Professional, Managerial, and Technical Vocations)

\begin{tabular}{|c|c|c|c|c|c|c|}
\hline & \multicolumn{3}{|c|}{ All Recent Immigrant Workers } & \multicolumn{3}{|c|}{$\begin{array}{l}\text { Recent Immigrant Workers with } \\
\text { Non-English Mother Tongues }\end{array}$} \\
\hline & Service & & & Service & & \\
\hline Variable & $\begin{array}{l}\text { Sales, and } \\
\text { Clerical }\end{array}$ & $\begin{array}{l}\text { Laborer and } \\
\text { Blue Collar }\end{array}$ & Agriculture & $\begin{array}{l}\text { Sales, and } \\
\text { Clerical }\end{array}$ & $\begin{array}{l}\text { Laborer and } \\
\text { Blue Collar }\end{array}$ & Agriculture \\
\hline \multirow[t]{2}{*}{$\overline{\mathrm{LEP}}$} & 0.293 & $1.156 * * *$ & 0.233 & 0.04 & $1.019 * * *$ & 0.086 \\
\hline & $(0.331)$ & $(0.268)$ & $(0.326)$ & $(0.378)$ & $(0.314)$ & $(0.370)$ \\
\hline \multirow[t]{2}{*}{ LEP x 1910 IPUMS } & S $\quad-0.468$ & $0.638 *$ & $0.966 * *$ & 0.273 & $0.782 * *$ & $1.234 * * *$ \\
\hline & $(0.401)$ & $(0.330)$ & $(0.392)$ & $(0.444)$ & $(0.369)$ & $(0.433)$ \\
\hline \multirow[t]{2}{*}{ LEP x 1920 IPUMS } & 0.222 & $0.806^{*}$ & $2.379 * *$ & 0.615 & $0.851 * *$ & $2.334 * * *$ \\
\hline & $(0.524)$ & $(0.439)$ & $(0.500)$ & $(0.566)$ & $(0.474)$ & $(0.539)$ \\
\hline \multirow[t]{2}{*}{ Literate } & $-1.067 * * *$ & $-0.965^{* * *}$ & $-1.117 * * *$ & $-1.133 * * *$ & $-0.808 * *$ & $-1.169 * * *$ \\
\hline & $(0.410)$ & $(0.359)$ & $(0.398)$ & $(0.433)$ & $(0.375)$ & $(0.422)$ \\
\hline Literate $\mathrm{x}$ & $0.926^{*}$ & -0.056 & -0.265 & $0.934^{*}$ & -0.208 & -0.2 \\
\hline 1910 IPUMS & $(0.533)$ & $(0.456)$ & $(0.499)$ & $(0.553)$ & $(0.470)$ & $(0.520)$ \\
\hline Literate $\mathrm{x}$ & $1.393 * *$ & -0.367 & -0.481 & $1.474 * *$ & -0.474 & -0.329 \\
\hline 1920 IPUMS & $(0.676)$ & $(0.551)$ & $(0.600)$ & $(0.711)$ & $(0.569)$ & $(0.623)$ \\
\hline $\mathrm{N}$ & 8,671 & & & 7,350 & & \\
\hline Pseudo $R^{2}$ & 0.120 & & & 0.128 & & \\
\hline
\end{tabular}

***, **, * Statistically significant at the one, five, and ten percent levels.

Notes: The parentheses contain robust standard errors. The sample includes immigrant men ages 16 and above who reported an occupation and who arrived to the US within three years of each census. Other control variables and their interactions with the 1910 and 1920 IPUMS binary variables include age, years in the US, Southern and Eastern European, Asian, geographic region (base = Northeast), whether LEP status was missing, and a constant; the results for these additional variables can be obtained from the authors.

Table A2 further indicates that the influence of literacy on blue versus white collar employment did not significantly change during this time, suggesting that the shift away from higher-status jobs among recent LEP immigrant men was not solely driven by a growing importance of formal education for incoming immigrants. It appears, then, that immigrants who were unable to speak the English language shortly after migrating to the U.S. faced tighter labor market conditions in 1920 compared to their counterparts who arrived in earlier years.

\section{NOTES}

The authors would like to thank the anonymous reviewers for their insightful suggestions.

1. U.S. Census Bureau data show that the 13.5 million immigrants in 1910 accounted for 14.7 percent of the total U.S. population, while the 32.5 million immigrants in 2002 comprised 11.5 percent of the American population [e.g., U.S. Census Bureau, 2002].

2. See, for example, McManus, Gould, and Welch [1983], Chiswick and Miller [1995], Lazear [1999], and Dávila and Mora [2000a; 2000b].

3. To illustrate, only 46 Chinese immigrants entered the U.S. between 1820 and 1850, but in 1854 alone, 13,100 were admitted [Curran, 1975]. Moreover, in the $1820 \mathrm{~s}$, less than 6,000 Germans migrated to the U.S.; this number increased to 976,000 in the 1850s [Adams, 1993]. 
4. This legislation included (1) the Act of 1875 that barred "undesirable" immigrants (criminals and prostitutes), (2) the Immigration Acts of 1882 and 1891 that broadened this classification, and (3) the Chinese Exclusion Act of 1882 that essentially ended Chinese immigration and deprived them of U.S. citizenship [Immigration and Naturalization Service (INS), 1999; Painter, 1987; Garis, 1927]. Theodore Roosevelt followed this idea when he engineered the Gentleman's Agreement with Japan in 1907; although not technically binding, Roosevelt attained assurances that the Japanese government would not issue its citizens passports to the U.S. in exchange for the promise to avoid taking legal action against Japanese immigrants [Bailey 1934].

5. For example, Curran [1975, 115] recounts the murder of nine Italian immigrants in New Orleans by an angry mob in 1890, the lynching of an Italian immigrant by a group of miners in Colorado the same year, and the lynching of five Italian storekeepers in Louisiana in 1899.

6. Examples against minority languages involved the New Mexico territory's ongoing search for statehood during this time. Along with racial stereotypes, the widespread Spanish-language use in New Mexico led many to consider the area too foreign to incorporate into the union. Republican John Lind, for instance, objected in 1892 to the "perpetuation of a foreign tongue" as an "American citizen" [Larson, 1968]. Similarly, the New York Tribune lamented in 1886 that the territory of New Mexico could not become a state because its inhabitants often used the Spanish language to the exclusion of English.

7. Congress passed this act in 1917 after overriding President Wilson's second veto. Attempts had been made to pass the literacy provision since 1896, but Presidents Cleveland, Taft, and Wilson vetoed it on the grounds that a literacy test only reflected immigrants' pre-migration opportunities and not their intellectual capacity or moral worth [Archdeacon, 1983; Wittke, 1949; Fairchild, 1917; Roberts, (1912) 1914]. Beyond the literacy test, this act banned immigrants belonging to "revolutionary organizations", migrating from an Asiatic "barred zone" (including Hindu and East India), or who could not pay the $\$ 8.00$ head tax. The Act of 1882 had established a head tax of $\$ 0.50$, which increased to $\$ 4.00$ in the Immigration Act of 1907 [INS, 1999].

8. Part of the reason Congress succeeded in passing the 1917 Immigration Act by overriding a presidential veto stemmed from growing concerns (often in the guise of national security) during World War I over the assimilability of the new immigrants, frequently measured by their relatively poor English fluency, low U.S.-citizenship attainment, and maintenance of native customs [e.g., King, 2000]. For example, in a January 1918 memorandum, the Federal Council of National Defense identified two problems with immigrants: the threat of sedition and the lack of English fluency among foreign-born workers. A related example is noted by Stephenson [1926] in which Congress legislated in 1917 that foreign-language publications pertaining to the War had to file translations with the postmaster unless the government was satisfied with the company's loyalty.

9. Stephenson [1926], Higham [1988], Adams [1993], and King [2000] provide specific examples, such as the passage of state legislation in the 1910s forbidding the use and teaching of non-English languages in schools and religious services. Iowa's governor further proclaimed in 1918 that non-English languages would not be used in public conversations or on the telephone. Many states also advocated universities to create programs on how to teach English and Americanization to the foreign-born during this time. Oregon further enacted a measure in 1920 that made it illegal for the publication, printing, circulation, exhibition, or sale of any work in a non-English language (including pamphlets and circulars) unless it contained English translations.

10. A period description by Hapgood [1902, 10-11] illustrates the perceived status of English by noting that the average immigrant "picks up only about a hundred English words and phrases...Of this modest vocabulary he is very proud, for it takes him out of the category of the 'greenhorn'...The man who has been only three weeks in this country hates few things so much as to be called a 'greenhorn'..."

11. Qualitative evidence of this is observed in Roberts [(1912) 1914, 81]: "Print the regulations in as many tongues as there are races employed; that will not help men who must in the daily process of production communicate with one another. They must have a common medium of communication, and the only rational solution of the difficulty is to teach all foreigners employed in hazardous industries enough English to enable them to understand simple instruction, to read simple warnings, and to communicate with one another."

12. The observation by Archdeacon [1983, 152] that "between 1899 and World War I technological developments decreased sharply the capacity of the American economy to absorb unskilled labor" further supports this notion, given that many low-skilled immigrants also lacked English fluency. 
13. For example, as noted in the Appendix, women represented only 15 percent of all recently-arrived immigrant workers in 1900, 1910, and 1920.

14. It should be noted that in the 1920 IPUMS, 929 out of the 51,965 immigrants ages 16 and above with non-English mother-tongues had missing information on English fluency. We exclude such individuals from our analyses in this study; the empirical results reported below remain primarily unchanged when assuming they were non-English-speakers.

15. This odds ratio describes the ratio of speaking English to being LEP in 1920 divided by this ratio for 1900 or 1910. For example, 36.7 percent of recent immigrants spoke English in 1910; their English fluent/LEP ratio equals $0.58=36.7 /(100-36.7)$, suggesting that recent immigrants were 0.58 times as likely to be English fluent instead of LEP in 1910. 62.8 percent of the sample spoke English in 1920; their English fluent/LEP ratio is $1.69=62.8 /(100-62.8)$. The 1920/1910 odds ratio, then, is 2.91 $=1.69 / 0.58$.

16. For example, see Note 2 as well as Espenshade and Fu [1997]; Espinosa and Massey [1997]; Stevens [1992]; and Jasso and Rosenzweig [1989].

\section{REFERENCES}

Adams, W. P. The German Americans: An Ethnic Experience, translated into English by L. J. Rippley and E. Reichmann. Indianapolis: Max Kade German American Center, Indiana University-Purdue University Indianapolis, 1993. Internet site: http://www.ulib.iupui.edu/kade/adams/toc.html.

Archdeacon, T. J. Becoming American: An Ethnic History. New York: The Free Press, 1983.

Bailey, T. A. Theodore Roosevelt and the Japanese American Crisis (Reprint 1964). Stanford CA: Stanford University Press, 1934.

Becker, G. S. The Economics of Discrimination, 2nd ed. Chicago IL: University of Chicago Press, 1971.

Blau, F. D. Immigration and Labor Market Earnings in Early Twentieth Century America., in Research in Population Economics: A Research Annual, Volume 2, edited by J. L. Simon and J. DaVanzo. Greenwich, CT: JAI Press, Inc., 1980, 21-41.

Bodnar, J. The Transplanted: A History of Immigrants in Urban America. Bloomington IN: Indiana University Press, 1985.

Chiswick, B. R., and Miller, P. W. The Endogeneity between Language and Earnings: International Analyses. Journal of Labor Economics, April 1995, 246-88.

Cohn, R. L. Nativism and the End of the Mass Migration of the 1840s and 1850s. Journal of Economic History, June 2000, 361-383.

Commons, J. R. Races and Immigrants in America (Reprint 1911). New York: The MacMillan Company, 1907.

Curran, T. J. Xenophobia and Immigration: 1820-1930. Boston: Twayne Publishers, 1975.

Dávila, A., and Mora, M. T. The English Fluency of Recent Hispanic Immigrants to the United States in 1980 and 1990. Economic Development and Cultural Change, January 2000a, 369-89.

. The English-Skill Acquisition of Hispanic Americans during the 1980s. Social Science Quarterly, March 2000b, 261-275.

Espenshade, T. J., and Fu, H. An Analysis of English-Language Proficiency Among U.S. Immigrants. American Sociological Review, April 1997, 288-305.

Espinosa, K. E., and Massey, D. S. Determinants of English Proficiency among Mexican Migrants to the United States. International Migration Review, Spring 1997, 28-50.

Fairchild, H. P. The Literacy Test and Its Making. Quarterly Journal of Economics, May 1917, 447460.

Garis, R. L. Immigration Restriction: A Study of the Opposition to and Regulation of Immigration into the United States. New York: The MacMillan Company, 1927.

Handlin, O. The Uprooted: The Epic Story of the Great Migrations that Made the American People. Boston: Little Brown, 1951.

Hapgood, H. The Spirit of the Ghetto: Studies of the Jewish Quarter in New York. New York: Funk and Wagnalls Company, 1902, 10-11, as quoted in After Ellis Island: Newcomers and Natives in the 1910 Census, edited by S. C. Watkins. New York: Russell Sage Foundation, 1994, 30.

Higgs, R. Race, Skills, and Earnings: American Immigrants in 1909. Journal of Economic History, June 1971, 420-429. 
Higham, J. Strangers in the Land: Patterns of American Nativism, 1860-1925. New Brunswick: Rutgers University Press, 1988.

Hourwich, I. A. Immigration and Labor: The Economic Aspects of European Immigration to the United States. New York: G. P. Putnam's Sons, 1912, 289, as quoted by R. Higgs. Race, Skills, and Earnings: American Immigrants in 1909. Journal of Economic History, June 1971, 420-29.

Immigration and Naturalization Service (INS). Immigration and Naturalization Legislation from the Statistics Yearbook. Internet: http://www.ins. usdoj.gov/graphics/aboutins/statistics/legishist/ index.htm, last modified July 7, 1999.

Jasso, G. and Rosenzweig, M. R. Language Skill Acquisition, Labor Markets, and Locational Choice: The Foreign-Born in the United States, 1900 and 1980, in Migration and Labor Market Adjustment, edited by J. Van Dijk, F. Hendrik, H. W. Herzog Jr., and A. M. Schlottman. Dordrecht, The Netherlands: Kluwer Academic Press, 1989, 217-239.

King, D. Making Americans: Immigration, Race, and the Origins of the Diverse Democracy. London: Harvard University Press, 2000.

Larson, R. W. New Mexico's Quest for Statehood 1846-1912. Albuquerque: University of New Mexico Press, 1968.

Lazear, E. P. Culture and Language. Journal of Political Economy, December 1999, S95-S126.

McGouldrick, P. F., and Tannen, M. B. Did American Manufacturers Discriminate against Immigrants before 1914? Journal of Economic History, September 1977, 723-746.

McManus, W., Gould, W., and Welch, F. Earnings of Hispanic Men: The Role of English Language Proficiency. Journal of Labor Economics, April 1983, 101-130.

Nugent, W. Crossings: The Great Transatlantic Migrations, 1870-1914. Bloomington: Indiana University Press, 1992.

Painter, N. I. Standing at Armageddon: The United States, 1877-1919. New York: W. W. Norton \& Company, 1987.

Roberts, P. The New Immigration: A Study of the Industrial and Social Life of Southeastern Europeans in America (Reprinted 1912). New York: MacMillan Company, 1914

Roy, A. D. Some Thoughts on the Distribution of Earnings. Oxford Economic Papers, June 1951, 13546.

Ruggles, S., and Sobek, M. Integrated Public Use Microdata Series, Version 2.0. University of Minnesota, Minneapolis: Historical Census Projects, 1997.

Smith, W. C. Americans in the Making: The Natural History of the Assimilation of Immigrants. New York: D. Appleton-Century Company, Inc., 1939.

Stephenson, G. M. A History of American Immigration: 1820-1924. Boston: Ginn and Company, 1926.

Stevens, G. The Social and Demographic Context of Language Use in the United States. American Sociological Review, April 1992, 171-185.

Viscusi, W. K. Sex Differences in Worker Quitting. Review of Economics and Statistics, April 1980, 38898.

Wittke, C. Immigration Policy Prior to World War I. Annals of the American Academy of Political and Social Science, 1949, 262, 5-14, reprinted in Immigration and the United States, edited by P. Tyler, New York: H.W. Wilson Company, 1956.

U.S. Bureau of the Census, Ethnic and Hispanic Statistics Branch, Population Division. Table 1.1: Population by Sex, Age, and Citizenship Status, 2002. Internet release date: March 23, 2003; http://www.census.gov/population/socdemo/foreign/ppl-162/tab01-01.pdf.

U.S. Bureau of Citizenship and Immigration Services. Table 1. Immigration to the United States: Fiscal Years 1820 - 2000. 2002. Internet site: http://www.immigration.gov/graphics/shared/aboutus/ statistics/IMM00yrbk/ExcIMM00/Table1.xls. 